\title{
Aplikasi EM-Conductivity Sistem Loop Vertical Coplanar untuk Identifikasi Sebaran Pupuk pada Lahan Pertanian di Sungai Raya, Kubu Raya, Kalimantan Barat
}

\author{
Triandi Kuseno1), Joko Sampurno ${ }^{1)}$, Yudha Arman ${ }^{1)}$ \\ 1)Program Studi Fisika Fakultas Matematika dan Ilmu Pengetahuan Alam \\ Universitas Tanjungpura \\ Pontianak, Indonesia \\ Email: triandi.kuseno@gmail.com
}

\begin{abstract}
Abstrak
Telah diidentifikasi sebaran pupuk pada lahan pertanian berdasarkan perubahan konduktivitas tanahnya. Metode yang digunakan untuk mengidentifikasi perubahan konduktivitas tanah adalah EM-Conductivity dengan sistem Loop Vertical Coplanar (VCP). Kedalaman pengukuran sistem VCP mencapai 3 meter dari permukaan tanah dan cukup untuk menjangkau zona efektif akar. Pengukuran dilakukan sebelum dan setelah pemupukan dengan variasi ketinggian perangkat dari permukaan tanah. Hasil setelah pemupukan menunjukkan penurunan konduktivitas tanah pada kedalaman 1 meter, peningkatan konduktivitas yang cukup besar pada kedalaman 2 meter dan peningkatan konduktivitas yang tidak terlalu besar pada kedalaman 3 meter. Sebaran pupuk diduga berada pada kedalaman 2 meter selama sepekan setelah pemupukan.
\end{abstract}

Kata kunci : EM, gambut, konduktivitas, pupuk, VCP

\section{Pendahuluan}

Sungai Raya merupakan kecamatan yang terletak di Kabupaten Kubu Raya, Kalimantan Barat. Daerah ini merupakan Daerah Aliran Sungai (DAS) pada dataran rendah dengan topografi relatif datar. Jenis tanah pada daerah ini merupakan tanah aluvial dengan sedikit lapisan tanah gambut. Menurut Badan Pusat Statistik (2009), pada tahun 2008 tanaman padi jumlah produksinya sebesar 200.484 ton dengan rincian padi sawah sebanyak 196.308 ton dan padi ladang 4.176 ton. Karena itu perlu adanya upaya berkelanjutan dalam peningkatan produktivitas yang disektor pertanian guna memenuhi ketahanan pangan.

Salah satu faktor penyebab kesuburan suatu lahan adalah adanya cadangan air tanah dan kandungan unsur hara yang lengkap. Pada umumnya, lahan pertanian di Kalimantan Barat merupakan lahan pertanian dengan menggunakan tanah gambut yang bersifat masam dan miskin hara, sehingga perlu adanya penyesuaian kondisi tanah dengan pemupukan yang tepat agar memenuhi $\mathrm{pH}$, kadar abu, kadar $\mathrm{N}, \mathrm{P}, \mathrm{K}$ dan kejenuhan basa yang optimal untuk pertumbuhan tanaman.

Sifat fisis tanah yang akan dikaji dalam penelitian ini adalah nilai konduktivitas tanah. Nilai konduktivitas tanah sangat dipengaruhi oleh material-material penyusun dari tanah itu sendiri, karena itu pemupukan pada lahan pertanian akan memperlihatkan perubahan nilai konduktivitas tanah. Dengan menganalisis perubahan konduktivitas tanah, maka dapat diprediksi distribusi pupuk pada lahan pertanian. Davis, et. al., (1997) telah mengkarakterisasi tanah dengan menggunakan induksi elektromagnetik menggunakan EM-38 dan Corwin, et. al., (2005) telah melakukan investigasi konduktivitas semu tanah di bidang pertanian pada lahan gersang. Karena itu metode geofisika yang sesuai untuk mengkaji kasus ini adalah metode Elektromagnetik, khususnya dengan menggunakan EMConductivity. Hasil penelitian ini diharapkan dapat memberikan informasi sebaran pupuk pada lahan pertanian dan menjadi salah satu pertimbangan kesesuaian lahan pertanian.

\section{Landasan Teori}

\subsection{Karakteristik Tanah Gambut}

Mengetahui karakteristik tanah gambut secara fisis maupun kimia sangatlah penting untuk pengolahan lahan gambut sebagai bidang pertanian yang optimal. Sifat fisis gambut yang spesifik yaitu berat isi (bulk density) yang rendah berimplikasi terhadap daya menahan beban tanaman yang rendah. Selain itu agar tanah gambut dapat dipergunakan dalam jangka waktu yang lama, maka laju subsiden (penurunan permukaan tanah) dan sifat mengering tidak balik (irreversible drying) perlu dikendalikan agar gambut tidak cepat habis. Sifat kimia seperti pH, kadar abu, kadar N, P, K, kejenuhan basa (KB), dan hara mikro merupakan informasi yang perlu diperhatikan dalam pemupukan di tanah gambut.

Karakteristik kimia lahan gambut sangat ditentukan oleh kandungan, ketebalan, dan jenis mineral pada substratum (di dasar gambut), 
serta tingkat dekomposisi gambut. Kandungan mineral gambut di Indonesia umumnya kurang dari 5\% dan sisanya adalah bahan organik. Fraksi organik terdiri dari senyawa-senyawa humat sekitar 10\% hingga 20\% dan sebagian besar lainnya adalah senyawa lignin, selulosa, hemiselulosa, lilin, tannin, resin, suberin, protein, dan senyawa lainnya (Balai Penelitian Tanah, 2011).

Perlu diketahui bahwa perubahan nilai konduktivitas tanah merupakan akibat dari terbawanya mineral pupuk oleh air yang menjadi larutan elektrolit. Larutan elektrolit adalah suatu senyawa yang bila dilarutkan dalam pelarut (misalnya air) akan menghasilkan larutan yang dapat menghantarkan arus listrik (Chang, 2005).

\subsection{Induksi Elektromagnetik}

Survei elektromagnetik (EM) pada dasarnya diterapkan untuk mengetahui respon bawah permukaan menggunakan perambatan gelombang elektromagnetik yang terbentuk akibat adanya arus bolak-balik dan medan magnetik. Medan magnet primer dihasilkan oleh arus bolak-balik yang melewati sebuah kumparan yang terdiri dari lilitan kawat. Respons bawah permukaan berupa medan magnet sekunder dan resultan medan terdeteksi sebagai arus bolak-balik yang menginduksi arus listrik pada koil penerima (receiver) sebagai akibat adanya induksi medan magnetik (Kearey et al., 2002). Adapun lebih jelasnya dapat dilihat pada gambar berikut:

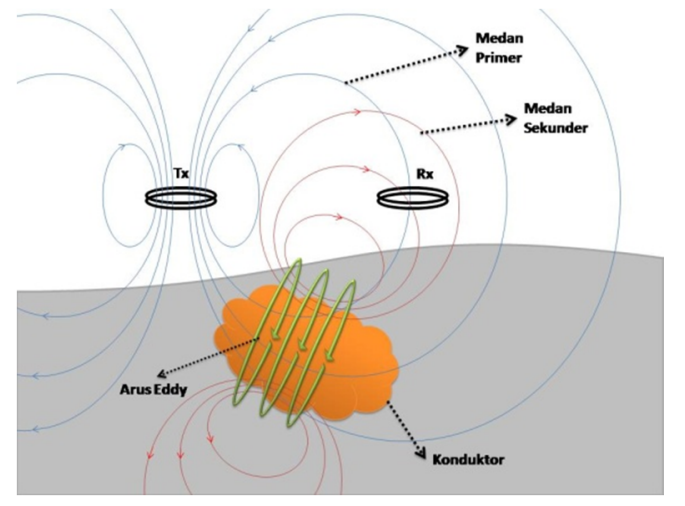

Gambar 1. Induksi medan elektromagnetik Sumber: Reynolds (1997)

Medan magnet primer dihasilkan dengan melewatkan arus AC melalui kumparan kawat pada transmitter (Tx). Medan magnet primer akan merambat di atas dan di bawah permukaan tanah. Jika terdapat material konduktif di bawah permukaan, medan magnet primer yang berubah terhadap waktu akan menginduksi material tersebut sehingga muncul rotasi medan listrik (eddy current). Medan listrik tersebut membangkitkan medan magnet sekunder yang akan terdeteksi oleh receiver (Rx). Receiver juga mendeteksi medan magnet primer (medan yang dihasilkan adalah kombinasi dari primer dan sekunder yang berbeda dari medan primer dalam fase dan amplitudo). Setelah kompensasi untuk bidang utama (yang dapat dihitung dari posisi relatif dan orientasi dari kumparan), baik besaran dan fase relatif bidang sekunder dapat diukur. Perbedaan dalam bidang resultan dari medan primer memberikan informasi tentang geometri, ukuran dan sifat listrik dari konduktor bawah permukaan (Kearey et at., 2002).

Setelah mendapatkan perbedaan medan EM primer dan medan EM sekunder, dapat ditentukan konduktivitas dari mineral bawah permukaan tanah, diberikan persamaan sebagai berikut (Reynolds, 1997):

$$
\sigma_{a}=\frac{4}{\omega \mu_{0} s^{2}}\left(\frac{H_{S}}{H_{p}}\right)
$$

dengan,

$\sigma_{a} \quad=$ konduktivitas semu (Siemen $/ \mathrm{m}$ )

$H_{s} \quad=$ medan magnet sekunder $(\mathrm{A} / \mathrm{m})$

$H_{p} \quad=$ medan magnet $\operatorname{primer}(\mathrm{A} / \mathrm{m})$

$\omega \quad=2 \pi f, f$ adalah frekuensi gelombang EM ( $f$ dalam $\mathrm{Hz}$ )

$\mu_{0} \quad=$ permeabilitas vakum $\left(4 \pi \times 10^{-7} \mathrm{H} / \mathrm{m}\right)$

$\mathrm{S} \quad=$ jarak antara pemancar dan penerima (meter)

\subsection{Konfigurasi EM-Conductivity}

Konfigurasi EM-Conductivity yang bisa digunakan oleh perangkat GF-Instrument CMD-4 adalah sistem Loop Vertical Coplanar (VCP) dan Loop Horizontal Coplanar (HCP). VCP biasa disebut juga Horizontal Magnetic Dipole (HMD). Demikian juga pada HCP yang biasa disebut Vertical Magnetic Dipole (VMD). Penetrasi optimum untuk konfigurasi HCP dapat mencapai kedalaman 6 meter dan dapat direduksi menjadi kedalaman 3 meter dengan menggunakan konfigurasi VCP. Adapun susunan sistem VCP dan sistem HCP adalah sebagai berikut (Burger et al., 2004):

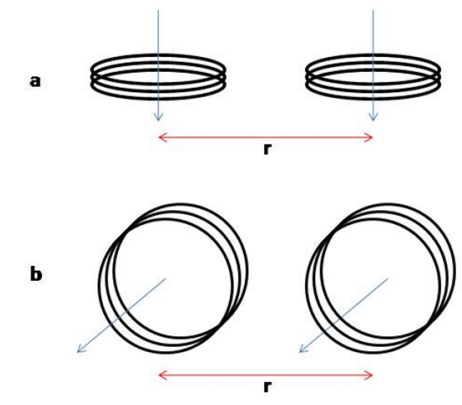

Gambar 2. Konfigurasi EM-Conductivity (a) sistem loop horizontal coplanar (HCP) dan (b) Sistem loop vertical coplanar (VCP) 
Untuk magnetik vertikal dengan sumber dipol terletak di $(0,0, h)$, komponen medan pada poin $(\mathrm{x}, \mathrm{y}, \mathrm{z})$ diberikan oleh persamaan (Sianturi, 2012):

$$
\begin{aligned}
H_{x}^{p} & =\frac{m_{T}}{4 \pi} \frac{3 x(z-h)}{R^{5}} \\
H_{y}^{p} & =\frac{m_{T}}{4 \pi} \frac{3 y(z-h)}{R^{5}} \\
H_{z}^{p} & =\frac{m_{T}}{4 \pi}\left[\frac{3(z-h)^{2}}{R^{5}}-\frac{1}{R^{3}}\right] \\
R^{2} & =r^{2}+(z-h)^{2} \text { dan } r^{2}=x^{2}+y^{2}
\end{aligned}
$$

Sedangkan untuk sumber dipol magnetik horisontal yang terletak di titik $(0,0, \mathrm{~h})$ dan menuju pada arah y, komponen medan primer pada titik $(\mathrm{x}, \mathrm{y}, \mathrm{z})$ diberikan oleh persamaan:

$$
\begin{aligned}
H_{x}^{p} & =\frac{m_{T}}{4 \pi} \frac{3 x y}{R^{5}} \\
H_{y}^{p} & =\frac{m_{T}}{4 \pi}\left[\frac{3 y^{2}}{R^{5}}-\frac{1}{R^{3}}\right] \\
H_{z}^{p} & =\frac{m_{T}}{4 \pi} \frac{3 y(z-h)}{R^{5}}
\end{aligned}
$$

Dengan $m_{T}$ adalah momen magnetik dari sumber dipol.

\subsection{GF Instrument $\mathrm{CMD}-4$}

Perangkat CMD-4 dari GF Instrument merupakan perangkat dengan spesifikasi yang sama seperti perangkat EM-31 dari Geonics. CMD-4 membangkitkan gelombang elektromagnetik sebagai konduktivitimeter dengan menggunakan frekuensi tetap sebesar 9,8 kHz dan jarak koil yang terpisah sejauh 3.66 meter. Perangkat ini dioperasikan dengan sumber tenaga 8 sel alkalin $\mathrm{C}$ yang mampu bertahan 15 hingga 30 jam. Pada kedua ujung yang terpisah sejauh 3.66 meter terdapat sebuah transmitter dan sebuah receiver (Frohlich, 1986).

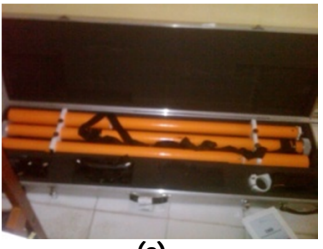

(a)

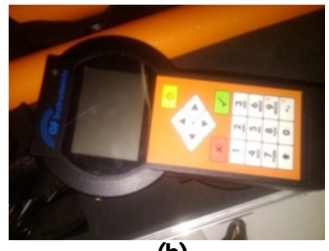

(b)
Gambar 3. Perangkat GF Instrument CMD-4 (a) Koil transmitter dan receiver dan (b) Perangkat main unit

\section{Metodologi}

Penelitian ini dilakukan di Desa Arang Limbung, Kecamatan Sungai Raya, Kabupaten Kubu Raya, Kalimantan Barat, dengan koordinat 49M X=0322384 Y=9986547 (sistem koordinat UTM). Pengambilan data dilakukan selama 10 hari, dengan 2 (dua) hari pengambilan data sebelum pemupukan dan 2 (dua) hari pengambilan data setelah 6 (enam) hari dari waktu pemupukan. Setelah itu dilakukan pengolahan data untuk menganalisis distribusi pupuk pada lahan pertanian.

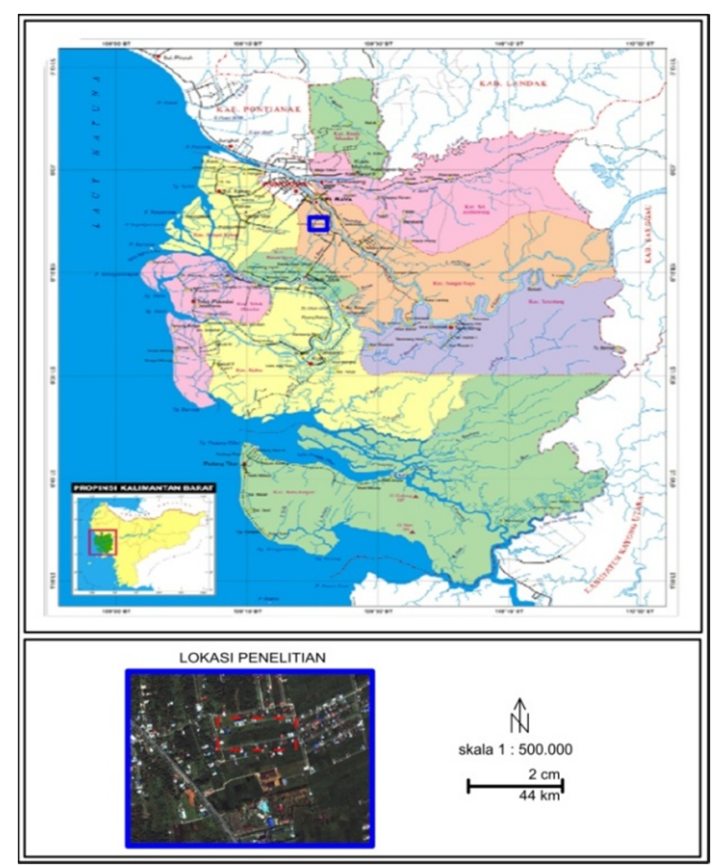

Gambar 4. Peta lokasi penelitian Sumber: Badan Pusat Statistik (2009)

\section{Hasil dan Diskusi}

\subsection{Distribusi konduktivitas tanah pada kedalaman 1 meter}

Kedalaman 1 meter didapatkan dengan konfigurasi VCP yang ditambah ketinggian 2 meter di atas permukaan tanah. Udara di atas permukaan tidak berpengaruh besar terhadap nilai konduktivitas yang terukur di bawah permukaan, sehingga nilai konduktivitas yang terukur adalah tanah pada kedalaman $0-1$ meter.

Kondisi pada gambar 5 menunjukkan distribusi nilai konduktivitas pada wilayah $1 \mathrm{~b}$ dan 3b menjadi lebih besar dibandingkan wilayah lainnya, yaitu sebesar 30 - $35 \mathrm{mS} / \mathrm{m}$. Akan tetapi, luas wilayah $1 \mathrm{~b}$ menjadi lebih kecil setelah pemupukkan. Diduga air yang membawa mineral pupuk telah bergerak ke lapisan bawah sehingga lapisan atas tanah menjadi kekurangan air yang membawa mineral pupuk.

Nilai konduktivitas pada wilayah $2 \mathrm{~b}$ menjadi kecil yaitu sebesar $24-28 \mathrm{mS} / \mathrm{m}$. Diduga air yang membawa mineral-mineral pupuk juga bergerak ke bawah akibat konduktivitas hidraulik tanah (permeabilitas tanah) yang besar. Jika permeabilitas tanah besar, maka semakin cepat air akan bergerak ke bawah permukaan dan menyebabkan lapisan tanah di atas menjadi kering. Lapisan tanah tersebut akan kekurangan mineral-mineral yang terbawa oleh air, sehingga konduktivitasnya akan menjadi kecil. 


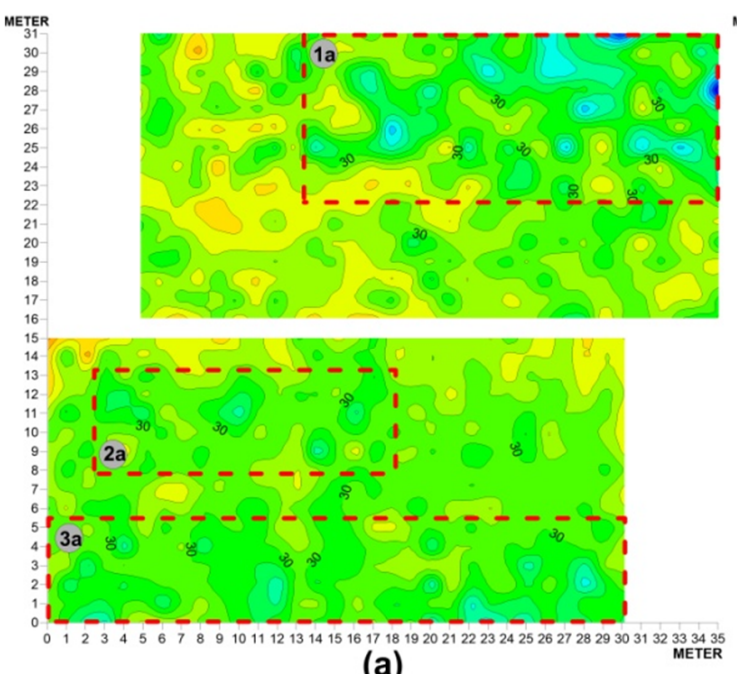

(a)

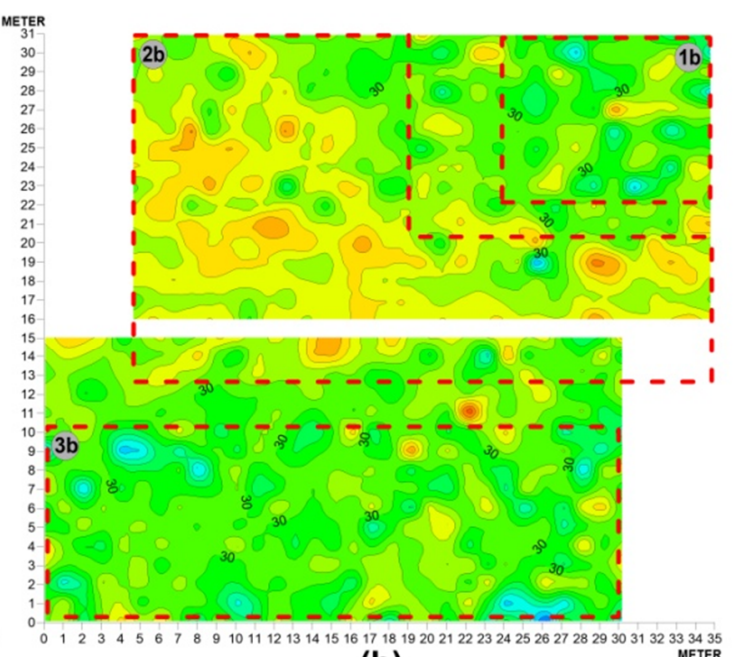

(b)

Gambar 5. Distribusi konduktivitas tanah kedalaman 1 meter (a) sesudah pemupukan (b) sebelum pemupukan

\subsection{Distribusi konduktivitas tanah pada kedalaman 2 meter}

Kedalaman 2 meter didapatkan dengan konfigurasi VCP yang ditambah ketinggian 1 meter di atas permukaan tanah. Udara di atas permukaan tidak berpengaruh besar terhadap nilai konduktivitas yang terukur di bawah permukaan, sehingga nilai konduktivitas yang terukur adalah tanah pada kedalaman $0-2$ meter.

Kondisi pada Gambar 6 menunjukkan distribusi nilai konduktivitas yang cukup besar terfokus pada wilayah 1a dengan nilai $45-53$ $\mathrm{mS} / \mathrm{m}$ dan wilayah $2 \mathrm{a}$ dengan nilai 45 - 51 $\mathrm{mS} / \mathrm{m}$. Posisi wilayah dengan nilai konduktivitas yang relatif besar juga sama seperti Gambar 5, hal tersebut menunjukkan tidak ada perbedaan

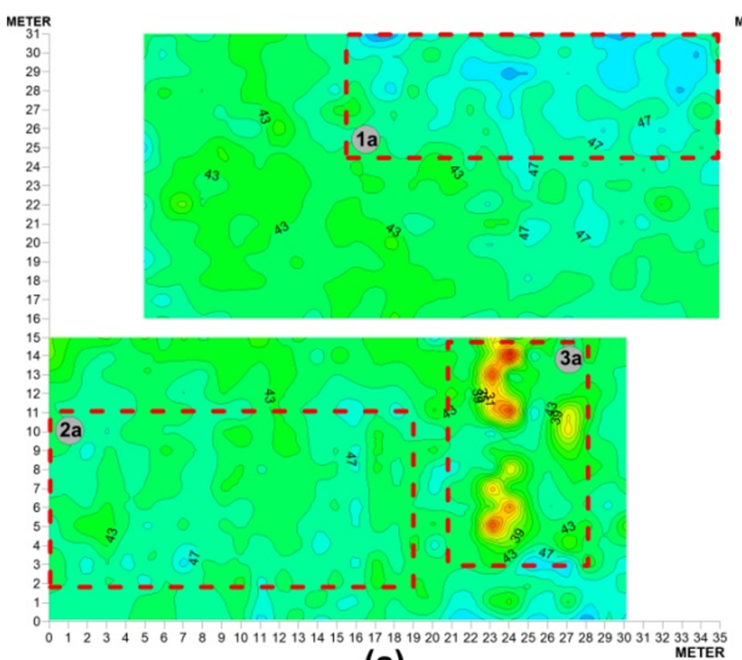

(a) profil tanah yang cukup kontras pada wilayah ini. Akan tetapi pada wilayah 3a menunjukkan nilai konduktivitas yang relatif kecil, yaitu 15 $37 \mathrm{mS} / \mathrm{m}$. Diduga pada wilayah 3a terdapat tanah dengan dengan kadar air yang rendah dan sulit untuk meloloskan air.

Pertambahan luas wilayah $1 \mathrm{~b}$ dengan nilai konduktivitas 45 - $53 \mathrm{mS} / \mathrm{m}$ menunjukkan perubahan yang cukup besar dibandingkan dengan sebelum pemupukan. Penambahan luas wilayah juga terjadi wilayah $2 \mathrm{~b}, 3 \mathrm{~b}$ dan $4 \mathrm{~b}$ dengan nilai konduktivitas yang relatif tinggi. Wilayah $2 \mathrm{~b}$ dengan menunjukkan rentang nilai konduktivitas tertinggi, yaitu sebesar 45 - 65 $\mathrm{mS} / \mathrm{m}$. Hal tersebut memperkuat dugaan bahwa air yang membawa mineral pupuk telah sampai ke lapisan ini.

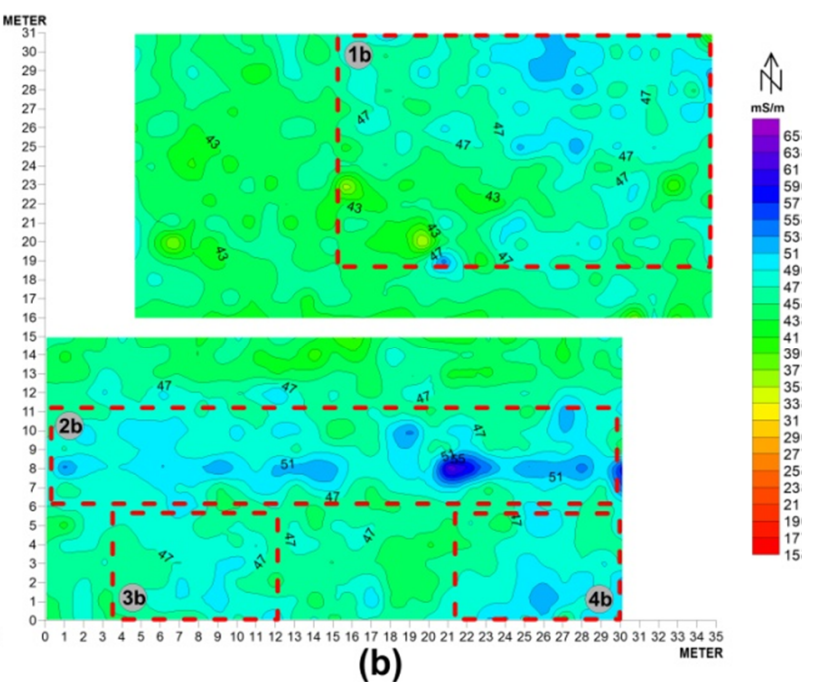

(b)

Gambar 6. Distribusi konduktivitas tanah kedalaman 2 meter (a) sesudah pemupukan (b) sebelum pemupukan 


\subsection{Distribusi konduktivitas tanah pada kedalaman 3 meter}

Kedalaman 3 meter didapatkan dengan konfigurasi VCP dengan posisi perangkat tepat pada permukaan tanah. Penetrasi medan magnet akan langsung menuju ke bawah permukaan, sehingga nilai konduktivitas yang terukur di bawah permukaan adalah tanah pada kedalaman 0 - 3 meter.

Kondisi Gambar 7 menunjukkan distribusi nilai konduktivitas yang relatif besar pada wilayah 1a dan 2a, yaitu sebesar $67-75 \mathrm{mS} / \mathrm{m}$, dengan wilayah terluas pada wilayah $2 \mathrm{a}$. Lapisan pada kedalaman ini menunjukkan besar nilai konduktivitas yang hampir merata, diduga sifat fisis dan kimia tanah aluvial yang lebih mempengaruhi nilai tersebut.

Posisi wilayah dengan nilai konduktivitas yang relatif besar terlihat konsisten dari lapisanlapisan sebelumnya. Diduga profil tanah pada wilayah 1a dan 2a merupakan tanah dengan

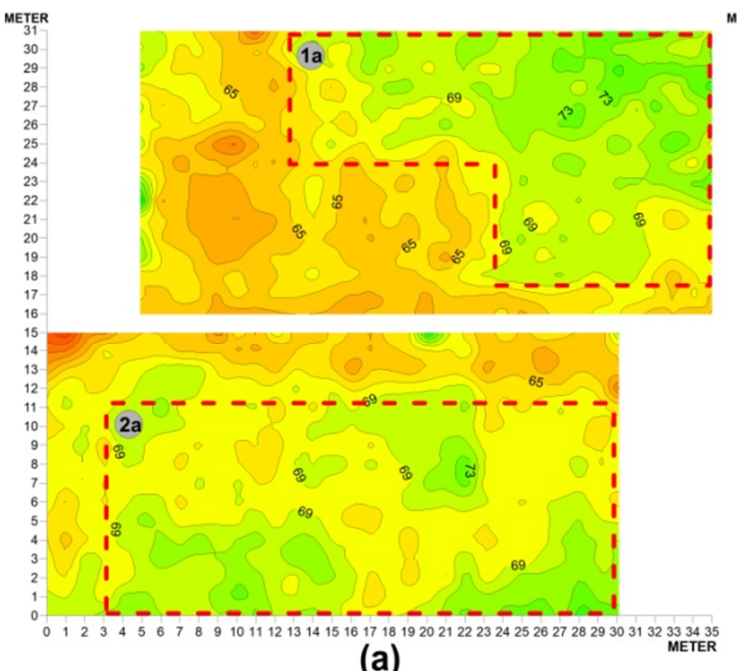

(a)

Gambar 7. Distribusi konduktivitas tanah kedalaman 3 meter (a) sesudah pemupukan (b) sebelum pemupukan

\subsection{Diskusi}

Perubahan nilai konduktivitas tanah merupakan akibat dari larutan elektrolit pupuk. Oleh karena itu, kandungan air pada tanah sangat berpengaruh terhadap perubahan nilai konduktivitasnya. Karena itu, analisis perubahan nilai konduktivitas tanah berdasarkan sifat fisis tanah yang berkaitan dengan kandungan air dan juga kemampuan tanah untuk meloloskan air (konduktivitas hidraulik tanah).

Nilai konduktivitas tanah juga dipengaruhi oleh $\mathrm{pH}$ tanah itu sendiri. Kondisi tanah pada lokasi penelitian merupakan tanah aluvial dengan sedikit lapisan gambut saprik (matang), artinya tanah aluvial dengan lapisan ketebalan gambut kurang dari $50 \mathrm{~cm}$. Kandungan asam kandungan air yang cukup besar dan juga memiliki sifat permeabilitas tanah yang besar dibandingkan wilayah lainnya. menunjukkan peningkatan nilai konduktivitas tanah. Peningkatan konduktivitas yang relatif besar dengan nilai $69-75 \mathrm{mS} / \mathrm{m}$ ditunjukkan pada posisi wilayah $1 \mathrm{~b}$ dan $2 \mathrm{~b}$. Posisi wilayah tersebut sudah menunjukkan nilai yang lebih besar dari saat sebelum pemupukan. Hal ini memperkuat dugaan bahwa air yang membawa mineral pupuk memang lebih terfokus pada wilayah $1 \mathrm{~b}$ dan $2 \mathrm{~b}$.

Sebaran nilai konduktivitas pada lapisan ini belum menunjukkan perubahan yang cukup besar bila dibandingkan pada kedalaman 2 meter. Distribusi nilai konduktivitas lapisan ini adalah pada rentang $63-73 \mathrm{mS} / \mathrm{m}$. Diduga air yang membawa mineral pupuk belum sepenuhnya sampai pada kedalaman 3 meter dan masih tertahan pada kedalaman 2 meter.

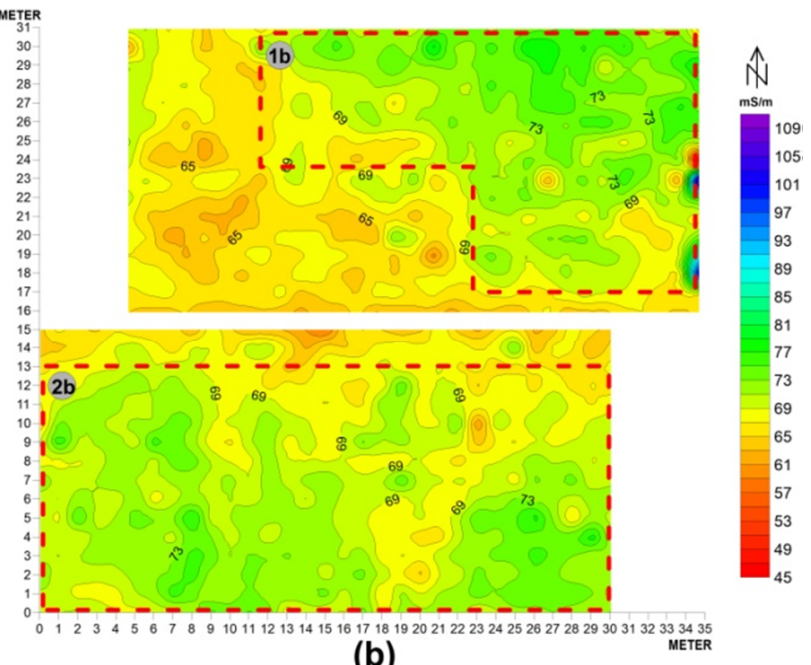

(b)
Lahan pertanian sesudah pemupukan

pada gambut, seperti asam humat dan asam fulvat, sangat berpengaruh terhadap peningkatan $\mathrm{pH}$ tanah. Pada jenis tanah ini lapisan gambut sudah mulai berkurang, sehingga kemasaman gambut cenderung menurun seiring bekurangnya ketebalan gambut.

Penambahan pupuk menjadi faktor yang paling dominan terhadap peningkatan nilai konduktivitas tanah karena mineral-mineral pupuk yang terion oleh air dan terserap tanah. Dengan demikian dapat dipetakan sebaran pupuk berdasarkan perubahan nilai konduktivitas tanah pada lahan pertanian sebagai berikut: 


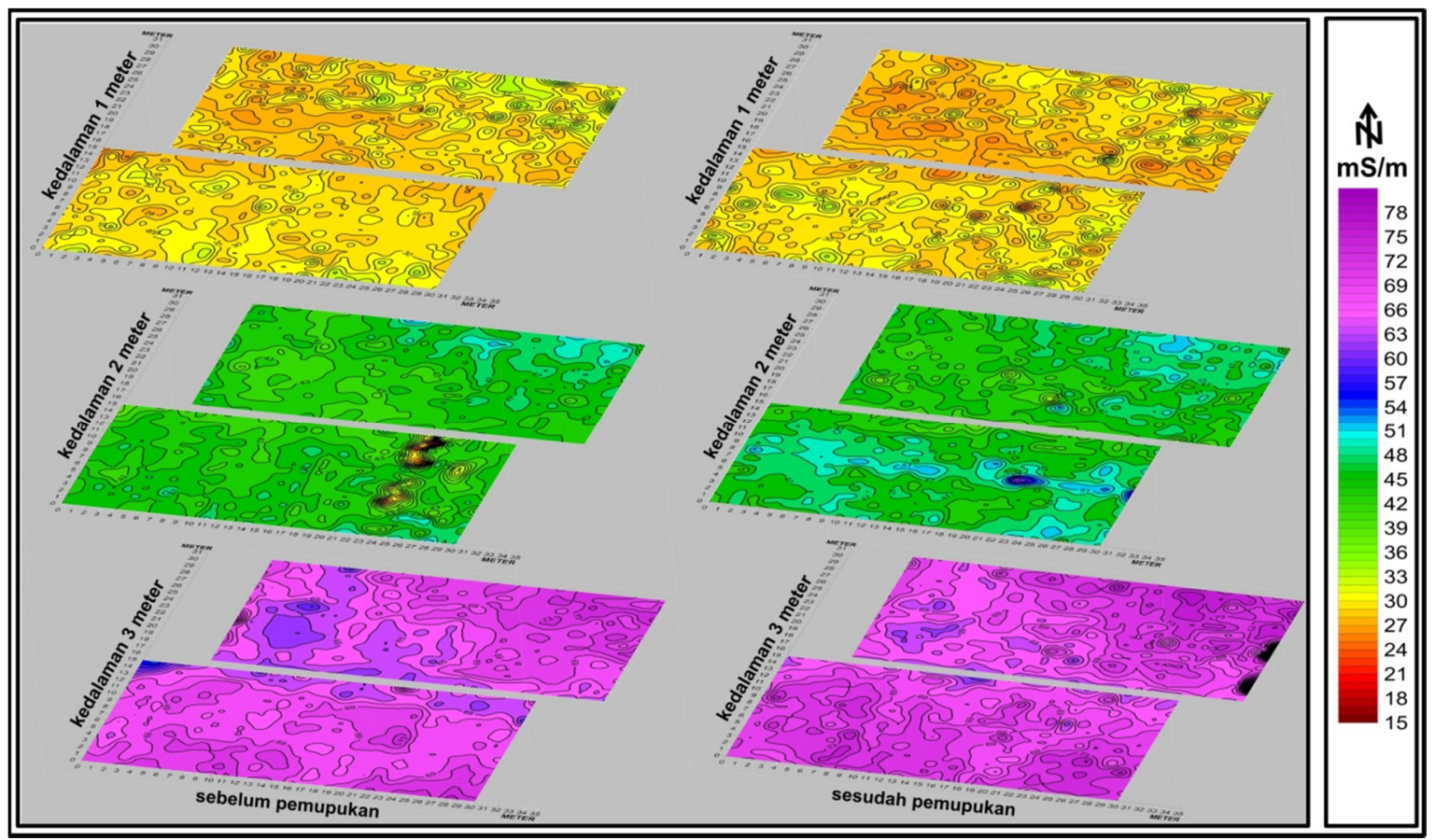

Gambar 8. Distribusi konduktivitas tanah sebelum dan sesudah dipupuk

\section{Kesimpulan}

Berdasarkan hasil analisis dapat disimpulkan bahwa setelah sepekan sebaran pupuk telah bergerak ke lapisan bawah dan terfokus pada lapisan kedalaman 2 meter dengan rentang nilai konduktivitas sebesar 45 $65 \mathrm{mS} / \mathrm{m}$ dan belum sepenuhnya sampai pada lapisan kedalaman 3 meter.

\section{Daftar Pustaka}

Badan Pusat Statistik, 2009, Kubu Raya Dalam Angka 2009. BPS Kabupaten Kubu Raya.

Balai Penelitian Tanah, 2011, Pengelolaan Lahan Gambut Berkelanjutan, Balai Penelitian Tanah, Bogor.

Burger, H. R., A. F. Sheehan, dan C. H. Jones, 2004, Introduction to Applied Geophysics Exploring The Shallow Subsurface. W.W. Norton, New York, London.

Chang, Raymond, 2005, Kimia Dasar (KonsepKonsep Inti), Edisi ketiga, Jilid 1, Erlangga, Jakarta.

Corwin, D. L. dan S. M. Lesch, 2005, Apparent Soil Electrical Conductivity Measurements in Agricultural, Computers and Electronics in Agriculture, 45, 11 - 43.

Corwin, D. L., S. M. Lesch dan D. A. Robinson, 2005, Apparent Soil Electrical Conductivity Measurements in Agricultural, Computers and Electronics in Agriculture, 46, 351 378.

Davis, J. G., N. R. Kitchen, K. A. Sudduth, S. T. Drummond, 1997, Using Electromagnrtic Induction to Characterize Soils, Missouri, 4, vol. 81.
Driessen, P. M. dan Soepraptohardjo, 1974, Soils for agricultural expansion in Indonesia. Soil Research Bull. No 1. Soil Research Institute, Bogor.

FAO, 1979, A Land Capability Appraisal Indonesia, Interm Report, United Nations Development Program, FAO, Roma.

Frohlic, Bruno, 1982, Electromagnetic Surveying in Current Middle Easter Archaelogy: Application and Evaluation, Society of Exploration Geophysicists Press, Washington DC.

Kearey, P., M. Brooks, dan I. Hill, 2002, An Introduction to Geophysical Exploration, Edisi ke-3, Blackweell Science Ltd, Malden, USA, Australia, Carlton, France.

Ratmini, Sri, 2012, Karakteristik dan Pengelolaan Lahan Gambut untuk Pengembangan Pertanian, Jurnal Lahan Suboptimal, 1, 197 - 206.

Reynolds, J. M., 1997, An Introduction to Applied and Environmental Geophysics, John Wiley \& Sons Ltd, England.

Sianturi, Guntur, 2012, Pemodelan dan Inversi Numerik untuk Sistem Loop-Loop Elektromagnetik Domain Frekuensi, Institut Teknologi Bandung, Bandung (Skripsi).

Suardi, Didi, 2002, Perakaran Padi dalam Hubungannya dengan Toleransi Tanaman terhadap Kekeringan dan Hasil, Jurnal Litbang Pertanian, 21 (3).

Telford, W. N., L. P. Geldard, R. E. Sherrif, dan D. A. Keys, 1976, Applied Geophysics, Cambridge University Press, Cambridge. 